\title{
Narracyjność językowego obrazu ludzkiej egzystencji w polskich i rosyjskich połączeniach wyrazowych zawierających czasowniki ruchu iść/udmu, chodzić/xodumb (na materiale leksykograficznym)
}

\author{
Narrativity of the linguistic picture of human existence \\ in Polish and Russian phrases containing the verbs \\ of movement iść/udmu, chodzić/xodumb \\ (on lexicographic material)
}

\begin{abstract}
The purpose of the study is to show narrative (narration) as a category that combines individual elements of knowledge, expressed through language, and, thus, ensures the cohesion of the linguistic and cultural picture of the world. In the light of this concept, the linguistic-cultural picture of the world is understood as a dynamic, multi-layered narrative depending on the accepted points of view, intentions, approaches and methods of conceptualization, categorization and axiologization of reality adopted in this culture. This article deals with the narrative of human life, which creates the expressions in Polish and Russian that contain verbs of movement. The analysis of the chosen phrases allows us to determine how similar life experiences are perceived in both languages, as well as to what extent the cultural conditions and the genetic proximity of both languages have an influence on similarities in the image of human existence.
\end{abstract}

Keywords: narrativity, linguistic and cultural, picture of the world, narrations about human life, Polish and Russian

Karina Zając-Haduch, Uniwersytet Pedagogiczny im. Komisji Edukacji Narodowej w Krakowie, Kraków - Polska, karina.zajac-haduch@up.krakow.pl, ORCID ID: https://orcid.org/0000-00016246-4909

Budowanie opowieści o życiu stanowi nieodłączny element ludzkiej egzystencji. „Co więcej, w nieskończonej niemal ilości form opowiadanie obecne jest we wszystkich czasach, wszystkich miejscach, wszystkich społeczeństwach. Narodziło się wraz z historią ludzkości” (Barthes 327). Jak zauważają badacze reprezentujący różne dyscypliny humanistyki, naturalność formy opowiadania, 
jako środka wyrażania myśli i stanów emocjonalnych, nie wynika z natury samego procesu komunikacji, ale ma swe źródło w narracyjnym sposobie pojmowania świata, który z kolei uwarunkowany jest narracyjną strukturą ludzkiej wiedzy o świecie (Trzebiński 17). Efektem narracyjnego sposobu postrzegania otaczającej nas rzeczywistości są dostarczane za pośrednictwem kultury gotowe wzorce, scenariusze standardowych (charakterystycznych dla danej społeczności) życiowych historii. Według Anny Pajdzińskiej, „nawet najbardziej spontaniczną, prywatną ekspresję indywidualnego przeżycia głęboko przenikają symboliczne systemy kultury, a jednostkowymi - zdawać by się mogło - interpretacjami sterują schematy narracyjne" (Pajdzińska 227-228). Przykładając określoną strukturę narracyjną do rzeczywistości, w której jesteśmy zanurzeni, umieszczamy dane wydarzenie w odpowiedniej czasoprzestrzeni i widzimy siebie i innych jako bohaterów rozmaitych historii. Istotne jest jednak, na co zwraca uwagę Jerome Bruner w swoim artykule Życie jako narracja, aby opowieści o życiu miały punkt zaczepienia w społeczności, z której wyrastają, aby narratorów i słuchaczy łączyła wspólna „struktura głęboka” dotycząca natury życia (Bruner 10).

Narracja jest zatem jedną z możliwych form organizacji doświadczenia, porządkującą naszą wiedzę o świecie społecznym, o ludziach i łączących ich relacjach, pozwalającą uchwycić upływ czasu, zyskać świadomość zmienności naszego życia i zachować poczucie własnej tożsamości:

Narracyjne opracowanie doświadczeń [...] prowadzi do uporządkowania zdarzeń, dostrzeżenia wśród nich pewnych spójnych sekwencji, odkrycia związków między poszczególnymi faktami (na przykład przyczynowo-skutkowych) i poprzez wszystkie te procesy pozwala zrozumieć własne doświadczenie i nadać mu znaczenie. W tym ujęciu [...] przynosi człowiekowi wglądy i odkrycia, odsłania lub konstruuje głębszy, bardziej ogólny sens zdarzeń (Stemplewska-Żakowicz, Zalewski 24-25).

Atrakcyjność pojęcia narracji, zdaniem niektórych badaczy, polega na jej strukturze czasowej: narracja (opowieść), podobnie jak ludzka egzystencja, ma swój początek, przebieg i koniec (Kotuła, Vojteková 14).

Przedmiotem niniejszych rozważań są narracje o ludzkim życiu, jakie tworzą utrwalone w języku polskim i rosyjskim wyrażenia zawierające czasowniki ruchu. Na podstawie analizy wybranych połączeń leksykalnych postaram się przedstawić, w jaki sposób w obu językach postrzegane są podobne doświadczenia życiowe, a także w jakim stopniu uwarunkowania kulturowe oraz genetyczna bliskość obu języków wpływają na zbieżności w obrazowaniu ludzkiej egzystencji.

Zdaniem przywoływanego wyżej Brunera ,[1]udzie, gdziekolwiek żyją, mogą przekazać jakąś zrozumiałą relację ze swojego życia. Różna w tych relacjach natomiast będzie kulturowa i językowa perspektywa i forma narracji, w którą zostanie 
ona ujęta i wyrażona" (Bruner 6). W świetle przytoczonych słów zasadne wydaje się przyjęcie za podstawę analizy teorii narracyjności jako kategorii zespalającej poszczególne elementy wiedzy, wyrażanej za pośrednictwem języka, a zatem nadającej spójność językowo-kulturowemu obrazowi świata. Językowo-kulturowy obraz świata, w świetle tej koncepcji, pojmowany jest jako dynamiczna, wielowątkowa narracja, uzależniona od przyjmowanych punktów widzenia, intencji, postaw oraz utrwalonych w danej kulturze sposobów kategoryzacji i aksjologizacji rzeczywistości (Filar 186). Warto podkreślić, że narracyjność, stanowiąca źródło głębokiej interdyscyplinarnej wiedzy dotyczącej sposobu konceptualizowania świata, w wielu aspektach odpowiada naturalnej, antropocentrycznej perspektywie języka, która uwzględnia „człowieka jako przedmiot językowej interpretacji” (Bartmiński, Tokarski 48).

Przyjrzenie się wybranym polskim i rosyjskim czasownikom ruchu iśćludmu, chodzićlxoдumb, ich derywatom prefiksalnym, a w szczególności utrwalonym w obu językach połączeniom leksykalnym (zwłaszcza frazeologicznym), w skład których wchodzą omawiane jednostki, pokazuje, w jakim stopniu 'chodzenie', czyli jedna z najwcześniej nabywanych przez człowieka umiejętności, wpływa na sposób postrzegania rzeczywistości i tworzenia narracji za pomocą środków językowych dostępnych w obu konfrontowanych językach. Należy zaznaczyć, że 'chodzenie' w świetle przeprowadzonej analizy to nie tylko czynność wykonywana przez człowieka, ale również odniesienie do stanów rzeczy, w których w pozycji wykonawcy czynności (agensa) występuje element rzeczywistości wyodrębniony przez człowieka w procesie metaforyzacji.

Wykorzystany materiał badawczy pochodzi z opracowań leksykograficznych, wśród których wymienić należy: Słownik języka polskiego pod redakcją Mieczysława Szymczaka (Szymczak 2002), Большой толковый словарь русского языка pod redakcją Siergieja Aleksandrowicza Kuzniecowa (Kuznecov 1998), Словарь-справочник по русской фразеологии Rudolfa Iwanowicza Jarancewa (Ârancev 1985), Фразеологический словарь русского языка pod redakcją Aleksandra Iwanowicza Mołotkowa (Molotkov 1986), Большой фразеологический словарь русского языка autorstwa Weroniki Nikołajewny Tielii (Teliâ 2006), Stownik frazeologiczny rosyjsko-polski pod redakcją Stanisława Karolaka (Karolak 1998), Wielki stownik polsko-rosyjski Dymitra Hessena, Ryszarda Stypuły (Hessen, Stypuła 1996), Wielki stownik polsko-rosyjski pod redakcją Magdaleny Kuratczyk, Elizy Małek, Jana Wawrzyńczyka (Kuratczyk, Małek, Wawrzyńczyk 2016).

Jak zauważa Irina Sandomirska, narracyjny charakter utrwalonych połączeń leksykalnych uwidacznia się w szczególny sposób, gdy utrwalone połączenia wyrazów nie są rozpatrywane pojedynczo, a łączy się je w mniej lub bardziej zorganizowane kompleksy (Sandomirska 363). Przeprowadzona analiza semantyczno-leksykalna 
polskich i rosyjskich jednostek leksykalnych tworzących narrację o ludzkiej egzystencji pozwala wyodrębnić kilka obszarów konceptualnych, do których odnieść można etapy ludzkiego życia, relacje międzyludzkie, stany emocjonalne oraz psychofizyczne. Liczną grupę w obu językach stanowią sfrazeologizowane wyrażenia w obrazowy sposób ukazujące poszczególne etapy ludzkiego życia, takie jak narodziny, dorastanie, zdobywanie wiedzy, rozpoczynanie samodzielnego życia, praca zawodowa, zarabianie, starzenie się i śmierć.

Bożena Kotuła i Marta Vojteková, porównując strukturę semantyczną polskich i słowackich czasowników ruchu, stwierdzają, że narrację o ludzkim życiu można zawrzeć w trzech zdaniach mocno podkreślających aktywność człowieka i stanowiących punkt wyjścia do dalszych opowieści:

1. Człowiek przychodzi na świat.

2. Człowiek idzie przez życie.

3. Człowiek odchodzi z tego świata (Kotuła, Vojteková 151).

Konfrontując te zdania z ich rosyjskimi odpowiednikami, można zauważyć podobne mechanizmy konceptualne i zbliżoną strukturę składniową ( идти no жизни, уходить/уйти в лучший мир, уходить/уйти из жизни), jedynie w rosyjskim frazeologizmie dotyczącym narodzin zaobserwować możemy wymianę czasownika przychodzić na pojawiać się. Powiemy zatem являться/появиться на свет: Скоро в семье появится ребенок; Я появился на свет последним (Kuznecov 951). Uwagę zwraca, zwłaszcza w rosyjskiej narracji, bogactwo synonimicznych konstrukcji obrazujących umieranie, zawierających zarówno derywaty prefiksalne czasowników ходить/идти: отходить/отойти в вечность; сходить/сойти в могилу, jak i inne charakterystyczne dla ruszczyzny czasowniki ruchu: ложсться/лечь в гроб (в могилу, в землю), отправляться/отправиться к праотиам; отправляться/отправиться на тот свет (Ârancev 193-197). Mnogość wyrażeń traktujących o sprawach ostatecznych może mieć swe źródło w specyfice rosyjskiego światopoglądu, w którym śmierć, stanowiąc istotny, a zarazem nieunikniony element ludzkiej egzystencji i obrzędowości, nie podlega tabuizacji (Zając-Haduch 323). Oswojenie lęku tanatycznego, zaprzestanie zaprzeczania, zaakceptowanie w przestrzeni psychicznej nieuchronnego końca ziemskiej wędrówki paradoksalnie pomaga bowiem zachować poczucie kontroli nad własnym życiem (Żelichowska 81-82).

W sfrazeologizowanych połączeniach leksykalnych realizujących metaforę pojęciową ŻYCIE to DROGA istotne miejsce zajmują związki wyrazowe opisujące proces dorastania, zdobywania wiedzy, rozpoczynania i kończenia kariery zawodowej. W większości z nich zaobserwować można bezpośrednią korespondencję językowo-kulturową pomiędzy językiem polskim i rosyjskim: wchodzić $w$ życie ( $w$ dorostość)/вступать в жизнь (во взрослость), iść do szkoty (na studia, do wojska)/идти (поступать) в школу (в вуз, на военную службу), iść na 
inżyniera (na nauczyciela)/идти в инженеры (в учителя), iść do pracy/uдти pаботать, pójść (odejść, przejść) na eтеryturę/перейти на пенсию.

Podobne analogie cechują narracje dotyczące wydarzeń związanych z życiem rodzinnym. W obu językach zmianę stanu cywilnego przez kobietę określa się za pomocą wyrażenia wychodzić (wyjśś) za maż/выходить (выйти) замуж, natomiast wychodząc za mąż bądź żeniąc się, kobieta bądź mężczyzna może wejść do rodziny/войти в семью.

Wynikającą z różnic kulturowo-obyczajowych wymianę elementu konstrukcji składniowej utworzonej na podstawie podobnych mechanizmów konceptualnych odnotować natomiast możemy w polskim połączeniu leksykalnym iść (z kimś) do ołtarza i jego rosyjskim odpowiedniku идти с кем-то под венеи. O ile w językowym obrazie świata Polaków wstąpienie w sakramentalny związek małżeński kojarzone jest z ołtarzem, czyli centralnym miejscem w świątyni, w tradycji cerkiewnej nacisk położony jest na obrzęd (венчание) nakładania na głowy osób zawierających związek małżeński ozdoby w postaci korony (венец) (Kuznecov 117).

Pozostając w kręgu narracji dotyczących życia rodzinnego, warto zwrócić uwagę na występujący w języku polskim frazeologizm opisujący odmienny kobiecy stan zajść w ciążę, który nie ma odpowiednika zawierającego czasownik ruchu w języku rosyjskim. Jego ekwiwalentem jest czasownik забеременеть.

Wśród związków wyrazowych dotyczących rozpoczynania samodzielnego życia, zarabiania na swoje utrzymanie, zakładania własnego gospodarstwa domowego w języku polskim można wyróżnić frazeologizm iść na swoje. Jego rosyjski odpowiednik jest wyrażony za pomocą innych środków językowych, wśród których nie ma czasownika ruchu - обзаводиться собственным хозяйством.

Podejmowane $\mathrm{w}$ trakcie samodzielnego życia działania mogą mieć różny przebieg i zarówno w języku polskim, jak i rosyjskim można odnaleźć wyrażenia, które to opisują. Wyrażenia te można podzielić na dwie grupy. Pierwszą tworzą frazeologizmy określające brak problemów, a nawet ukazujące podejmowane inicjatywy w kategoriach sukcesu: (coś) idzie po staremu (po dawnemu), swoim (dawnym, starym, zwyklym) torem (trybem, porzadkiem, zwyczajem), zwykla koleja/(что-л.) идет своим (прежним, обычнымм) чередом; (соś) idzie dobrze, jak w zegarku, jak po maśle, jak z płatka, po myśli/что-л. идет хорошо, как часы, как по маслу, согласно желанию; (ktoś) pnie się w górę/(кто-л.) идет в гору). W przypadku wymienionych połączeń leksykalnych w obu językach zaobserwować można zbliżone mechanizmy tworzenia metafor, takie same mechanizmy konceptualne i podobne struktury składniowe. Wyjątek w tej grupie stanowi frazeologizm zajść daleko ('osiągnąć w życiu coś ważnego, odnieść sukces'), którego strukturalny odpowiednik w języku rosyjskim зайти далеко ma zgoła odmienne znaczenie i jest stosowany w celu określenia braku opanowania, utraty 
kontroli nad sobą, swoimi emocjami, co w konsekwencji prowadzi do przekroczenia przyjętych norm zachowania: Я должен, однако ж, решительно сказать, что мы зашли далеко. Мой долг, моя обязанность сказать тебе это. - Что сказать?.. - Что мы делаем очень дурно, что видимся тайком (Гончаров, Обломов) (Molotkov 172).

Jeżeli chodzi o frazeologizmy z drugiej grupy, czyli nazywające trudności $\mathrm{w}$ realizacji podejmowanych działań, napotykane przeszkody i niepowodzenia, niektóre polskie wyrażenia nie mają odpowiedników w języku rosyjskim, a w większości przeanalizowanych konstrukcji rosyjskich nie występuje czasownik ruchu (obecny w polskich wyrażeniach): (coś) idzie jak po grudzie, na opak, nie tak jak należ/(что-л.) дается с большим трудом, наоборот, не так как полагается; (coś) nie dochodzi do skutku/(что-л.) не осуществляется; (coś) idzie na marne/(что-л.) пропадает зря (без пользы); (coś) idzie w niepamięć, w zаротпіепіе/(что-л.) подвергается забвению, забыьвается; (ktoś) idzie na bruk (na ulice)/(кто-л.) оказывается на улице.

$\mathrm{W}$ narracji o ludzkim życiu istotne są połączenia wyrazowe z czasownikami iść (przyjść)/uдти (прийти) w obrazowy sposób przedstawiające relacje międzyludzkie. Zachowania społeczne oparte na współpracy, współdziałaniu, respektowaniu potrzeb innych określają w języku polskim jednostki, których odpowiedniki rosyjskie (w większości) wyglądają jak ich lustrzane odbicie, tj. thumaczenie dosłowne: iść na ustępstwa, na koтpromis/uдти на уступки, на компромисс; iść (z kimś) ramię w ramię, ręka w rękę/uдти (с кем-то) рука об руку; przyjść (koтиś) z ротоса̨/прийти (кому-л.) на помощьь. Zarówno w języku polskim, jak i rosyjskim można spotkać frazeologizm opisujący pozytywnie wartościowaną gotowość do poświęceń dla drugiego człowieka: iść za kimś w ogień (na kraj świata)/идти в огонь и воду за кого-л.; Dla niej dzieci byty najważniejsze, pоszłaby za nimi w ogień. To była wzorowa matka („Dziennik Polski”, źródło elektroniczne); Неужели же это та самая Лидочка, молоденькая секретарша сельсовета, которая в огонь и в воду готова была пойти за ним? (Abramov, źródło elektroniczne).

W obu językach występują również frazeologizmy obrazujące takie postawy, jak zbytnia łatwowierność, podatność na manipulację: iść na lep/идти на удочку czy też uległość wobec innych, ślepe posłuszeństwo, bezwolne podporządkowywanie się: iść na (czyimś) pasku/uдти на поводу (у кого-л.). Samodzielne postępowanie, kierowanie się własnymi zasadami, niepoddawanie się wpływom innych ludzi wyraża połączenie wyrazowe iść swoją drogą, własnymi drogami/uдти своей дорогой. Na określenie determinacji w działaniu, a zarazem bezwzględności wobec osób stanowiących przeszkodę w dążeniu do celu w obu językach można odnaleźć tożsame wyrażenia: iść (kroczyć) po trupach/uдти (щагать) nо трynaм 'dążyć do czegoś, nie przebierając w środkach, niszcząc, krzywdząc ludzi'. 
Należy zaznaczyć, że w przywołanych związkach frazeologicznych zawarte jest zdecydowanie negatywne wartościowanie.

Kolejna grupa wyodrębnionych w toku analizy polskich i rosyjskich jednostek leksykalnych, tworzących narrację o ludzkiej egzystencji, odnosi się do stanów psychofizycznych, w tym procesów mentalnych. Dotyczą one m.in. możliwości intelektualnych człowieka. W języku polskim coś wchodzi do głowy, czyli 'łatwo się czegoś nauczyć, coś zrozumieć', zaś w języku rosyjskim zdolność szybkiego przyswajania wiedzy jest określana za pomocą konstrukcji bez czasownika ruchu: что-л. дается легко. Efekty procesów poznawczych znajdują swoje odzwierciedlenie w związkach wyrazowych, w których zaobserwować można zbieżność językowo-kulturową (w obu językach obecne są badane czasowniki ruchu, zróżnicowane są jedynie ich derywaty prefiksalne), np.: dochodzić do przekonanial приходить к убеждению; dochodzić do wniosku/nриходить к выводу; wychodzić z założenialucходить из того, что...

Wśród frazeologizmów odnoszących się do fizycznego i psychicznego zdrowia człowieka w obu językach można wyodrębnić związek leksykalny opisujący stan skrajnej złości, rozdrażnienia, wzburzenia spowodowanego czyimś zachowaniem, utraty panowania nad sobą: wychodzić z siebie/выхходить из себя. Należy mieć jednak na uwadze, że w języku polskim frazeologizm ten ma jeszcze jedno znaczenie nieodnotowane w jego rosyjskim odpowiedniku: 'bardzo się starać, robić wszystko, co możliwe': Tam na scenie, aktorzy wychodzili z siebie, aby zainteresować publiczność, gdy ona tymczasem zajęta byla podgladaniem, kto z kim w tych lożach przesiaduje (Korpus Języka Polskiego, źródło elektroniczne).

Odzyskiwanie równowagi psychicznej, opanowywanie złych emocji w języku polskim określa połączenie wyrazowe dochodzić do siebie. Jego rosyjskim odpowiednikiem jest приходить в себя: Вдруг Иван Иванович вскрикнул и обомлел: ему показался мертвеи; но скоро он пришел в себя, увидевши, что это был гусь (Gogol', źródło elektroniczne). Nagle Iwan Iwanowicz krzyknąt i zdrętwiat: ujrzal trupa; ale szybko doszedt do siebie, kiedy spostrzegt, że to była gęś (Karolak 869). Zarówno w języku polskim, jak i rosyjskim frazeologizm ten odnosi się również do sfery fizyczności i jest stosowany w znaczeniu 'odzyskiwać siły, wracać do zdrowia', 'odzyskiwać przytomność': Powrót do rzeczywistości, choćby nawet dość nieprzyjemnej, jest jednak uspokajajacy. Szaman dochodzi do siebie, jeszcze tylko ciężko oddycha. Gdy się obudzit, wydawało mu się, że jest na innej planecie (Varga, źródło elektroniczne); Только в Мюнхене Ефиму Анатольевичу удалось некоторым образом прийти наконеи в себя. Появилась краска на лице, стал спокойным сон, проснулся аппетит. А вместе с ним-интерес к окружающему (Neznanskij, źródło elektroniczne). Zaobserwować zatem możemy w przypadku tego frazeologizmu bezpośrednią korespondencję językowo-kulturową, bazującą na zakotwiczonej w tradycji (judeo)chrześcijańskiej meta- 
forze wyrażającej przekonanie, że powrót do normalnej aktywności życiowej jest możliwy dzięki „powrotowi” mentalnie-zmysłowego ,ja”, zdolnego do wyczuwania, postrzegania, doświadczania i oceniania, do wewnątrz pojemnika, za który służy powłoka cielesna (Krasnyh, źródło elektroniczne).

Podsumowując zaprezentowane rozważania, nie sposób nie zwrócić uwagi na podobieństwo wizji świata w utrwalonych w obu językach narracjach dotyczących ludzkiej egzystencji. Ze względu na uwarunkowania kulturowe i bliskie pokrewieństwo obu języków w ich zasobie leksykalnym spotykamy wiele zbliżonych konstrukcji, wyrażających także podobne znaczenia. Należy jednak zaznaczyć, że przeprowadzona analiza, obok związków leksykalnych, w których obserwujemy bezpośrednią korespondencję językowo-kulturową, pozwoliła wyodrębnić również:

- związki wyrazowe, w których zachowana jest ta sama konstrukcja składniowa i podobne mechanizmy konceptualne, ale wymieniony jest jakiś element (iść z kimś do oltarza/uдти с кем-то под венеи);

- frazeologizmy, które nie mają odpowiedników zawierających czasownik ruchu w jednym albo drugim języku (coś nie dochodzi do skutku/ymo-л. не осуществляется; идти против кого-л./występować przeciw koтиś);

- podobnie brzmiące w obu językach związki frazeologiczne, ale różniące się znaczeniem (zajść daleko 'osiągnąć sukces'/зайти далеко 'utraciwszy kontrolę nad sobą, przekroczyć przyjęte normy zachowania; posunąć się za daleko).

Nie ulega wątpliwości, że opis zapisanego w przebadanych związkach wyrazowych sposobu postrzegania rzeczywistości pozwala dostrzec językowo-kulturową perspektywę narracji. Jest to perspektywa antropocentryczna. Człowiek jako podmiot działań językowych wyodrębnia i wiąże ze sobą poszczególne zjawiska i fakty, nadaje im spójność w ramach językowego obrazu świata i tworzy tym samym kulturowo zinterpretowaną opowieść o życiu (Filar 67).

\section{Bibliografia}

Abramov, Fedor. Vokrug da okolo... Web. 14.10.2019. https://phrase_dictionary.academic.ru/913/ ИДТИ_В_ОГОНЬ_И_ВОДУ.

Ârancev, Rudol'f I., red. Slovar'-spravočnik po russkoj frazeologii. Moskva, Russkij âzyk, 1985.

Barthes, Roland. „Wstęp do analizy strukturalnej opowiadań”. Przeł. Wanda Błońska. Pamiętnik Literacki, 4, 1968, s. 327-359.

Bartmiński, Jerzy, Ryszard Tokarski. „Definicja semantyczna: czego i dla kogo?”. O definicjach $i$ definiowaniu. Red. Jerzy Bartmiński, Ryszard Tokarski. Lublin, Wydawnictwo Uniwersytetu Marii Curie-Skłodowskiej, 1993, s. 47-61.

Bruner, Jerome. „Życie jako narracja”. Kwartalnik Pedagogiczny, 4, 1990, s. 3-17. 
Dziennik Polski, 09.05.2003. Web. 14.10.2019. https://wsjp.pl/index.php?id_hasla=41890.

Filar, Dorota. Narracyjne aspekty językowego obrazu świata. Interpretacja marzenia we wspótczesnej polszczyźnie. Lublin, Wydawnictwo Uniwersytetu Marii Curie-Skłodowskiej, 2013.

Gogol', Nikolaj V. Povest'o tom, kak possorilsâ Ivan Ivanovič s Ivanom Nikiforovičem. Web. 14.10.2019. https://phraseology.academic.ru/9835/\%D0\%9F\%D1\%80\%D0\%B8\%D0\%B9\%D $1 \% 82 \% \mathrm{D} 0 \% \mathrm{~B} 8$ \%D0\%B2_\%D1\%81\%D0\%B5\%D0\%B1\%D1\%8F.

Hessen, Dymitr, Ryszard Stypuła, red. Wielki stownik polsko-rosyjski. Warszawa, Wiedza Powszechna, 1996.

Karolak, Stanisław, red. Stownik frazeologiczny rosyjsko-polski. Warszawa, Energeia, 1998.

Korpus Języka Polskiego, Web. 14.10.2019. https://sjp.pwn.pl/korpus/zrodlo/wychodzili-zsiebie; 1954,$3 ; 2944 . h t m l$.

Kotuła, Bożena, Marta Vojteková. „Narracyjność w strukturze semantycznej polskich i słowackich czasowników ruchu". Narracyjność języka i kultury. Red. Dorota Filar, Dorota Piekarczyk. Lublin, Wydawnictwo Uniwersytetu Marii Curie-Skłodowskiej, 2014, s. 147-159.

Krasnyh, Viktoriâ V. „Kul'turologičeskij kommentarij”. Web. 15.10.2019. https://phrase_dictionary. academic.ru/2037/ПРИХОДИТЬ_В_СЕБЯ).

Kuratczyk, Magdalena, Eliza Małek, Jan Wawrzyńczyk, red. Wielki słownik polsko-rosyjski. Warszawa, Państwowe Wydawnictwo Naukowe, 2016.

Kuznecov, Sergej A., red. Bol'šoj tolkovyj slovar' russkogo âzyka. Sankt-Peterburg, Norint, 1998.

Molotkov, Aleksandr I., red. Frazeologičeskij slovar' russkogo âzyka. Moskva, Russkij âzyk, 1986.

Neznanskij, Fridrih E. Prosročennaâ viza. Web. 15.10.2019. https://phrase_dictionary.academic.ru/ 2037/ПРИХОДИТЬ_В_СЕБЯ.

Pajdzińska, Anna. „Sposoby uobecniania się podmiotu w tekście”. Podmiot w języku i kulturze. Red. Jerzy Bartmiński, Anna Pajdzińska. Lublin, Wydawnictwo Uniwersytetu Marii Curie-Skłodowskiej, 2008, s. 225-239.

Sandomirska, Irina. „O metaforach ŻYCIA i ŚMIERCI w stałych związkach wyrazowych w języku rosyjskim”. Język a Kultura. T. 13: Językowy obraz świata i kultura. Red. Anna Dąbrowska, Janusz Anusiewicz. Wrocław, Wydawnictwo Uniwersytetu Wrocławskiego, 2000, s. 355-367.

Stemplewska-Żakowicz, Katarzyna, Bartosz Zalewski. „Czym jest dobra narracja? Struktura narracji z perspektywy badaczy i klinicystów". Badania narracyjne w psychologii. Red. Maria Straś-Romanowska, Bogna Bartosz, Magdalena Żurko. Warszawa, ENETEIA, Wydawnictwo Psychologii i Kultury, 2010, s. 17-52.

Szymczak, Mieczysław, red. Słownik języka polskiego. Warszawa, Państwowe Wydawnictwo Naukowe, 2002.

Teliâ, Veronika N., red. Bol'šoj frazeologičeskij slovar' russkogo âzyka. Moskva, AST-PRESS KNIGA, 2006.

Trzebiński, Jerzy. Narracja jako sposób rozumienia świata. Gdańsk, Gdańskie Wydawnictwo Psychologiczne, 2002.

Varga, Krzysztof. Chłopaki nie płacza. Web. 15.10.2019. https://sjp.pwn.p1/korpus/zrodlo/dochodzido-siebie; 61,3;3100.html.

Zając-Haduch, Karina. „Śmierć w językowym obrazie świata Rosjan”. Wspótczesne badania nad kultura, literaturą i językiem rosyjskim. Red. Dorota Paśko-Koneczniak. Toruń, Wydawnictwo Naukowe Uniwersytetu Mikołaja Kopernika, 2012, s. 315-325.

Żelichowska, Magdalena. „Śmierć z perspektywy psychospołecznej”. Śmierć jako norma - śmierć jako skandal. Red. Waldemar Kuligowski, Piotr Zwierzchowski. Bydgoszcz, Wydawnictwo Akademii Bydgoskiej, s. 80-85. 